ORDERS AND HIERARCHIES IN LATE MEDIEVAL AND RENAISSANCE EUROPE 
PROBLEMS IN FOCUS: MANCHESTER

General Editor: Brian Pullan

\author{
Published \\ Jeffrey Denton (editor) \\ Orders and Hierarchies in Late Medieval and \\ Renaissance Europe \\ Peter Lowe (editor) \\ The Vietnam War
}




\title{
ORDERS AND HIERARCHIES IN LATE MEDIEVAL AND RENAISSANCE EUROPE
}

\author{
Edited by \\ Jeffrey Denton \\ Research Professor of Medieval History \\ University of Manchester
}

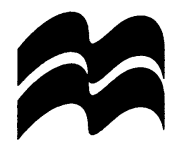


Selection, editorial matter and Introduction $\odot$ Jeffrey Denton 1999

Chapter 1 ( Stephen Rigby 1999; Chapter 2 ( $)$ Antony Black 1999;

Chapter 3 (C) Spencer Pearce 1999; Chapter 4 (C) Peter Ainsworth 1999;

Chapter 5 (C) Paul Binski 1999; Chapter 6 (C) Maurice Keen 1999;

Chapter 7 @ Michael Bush 1999; Chapter 8 @ David Rheubottom 1999;

Chapter 9 (C) Brian Pullan 1999

Softcover reprint of the hardcover 1st edition 1999 978-0-333-67765-0

All rights reserved. No reproduction, copy or transmission of this publication may be made without written permission.

No paragraph of this publication may be reproduced, copied or transmitted save with written permission or in accordance with the provisions of the Copyright, Designs and Patents Act 1988, or under the terms of any licence permitting limited copying issued by the Copyright Licensing Agency, 90 Tottenham Court Road, London WIP 9HE.

Any person who does any unauthorised act in relation to this publication may be liable to criminal prosecution and civil claims for damages.

The authors have asserted their rights to be identified as the authors of this work in accordance with the Copyright, Designs and Patents Act 1988.

First published 1999 by MACMILLAN PRESS LTD

Houndmills, Basingstoke, Hampshire RG21 6XS and London

Companies and representatives throughout the world

ISBN 978-0-333-67766-7 ISBN 978-1-349-27580-9 (eBook)

DOI $10.1007 / 978-1-349-27580-9$

A catalogue record for this book is available from the British Library.

This book is printed on paper suitable for recycling and made from fully managed and sustained forest sources.

$\begin{array}{lllllllllll}10 & 9 & 8 & 7 & 6 & 5 & 4 & 3 & 2 & 1\end{array}$

$\begin{array}{llllllllll}08 & 07 & 06 & 05 & 04 & 03 & 02 & 01 & 00 & 99\end{array}$ 


\section{CONTENTS}

List of Illustrations

Introduction

Jeffrey Denton

1 Approaches to Pre-Industrial Social Structure Stephen Rigby

2 European and Middle Eastern Views of Hierarchy and Order in the Middle Ages: A Comparison Antony Black

3 Dante: Order, Justice and the Society of Orders Spencer Pearce

4 Froissardian Perspectives on Late-Fourteenth-Century Society

Peter Ainsworth

5 Hierarchies and Orders in English Royal Images of Power

Paul Binski

6 Heraldry and Hierarchy: Esquires and Gentlemen Maurice Keen

7 The Risings of the Commons in England, 1381-1549 Michael Bush

8 Tidy Structures and Messy Practice: Ideologies of Order and the Practicalities of Office-Holding in Ragusa 
9 'Three Orders of Inhabitants': Social Hierarchies in the Republic of Venice

Brian Pullan

Notes and References

Bibliographical Guides

196

Index

203 


\section{LiST OF ILLUSTRATIONS}

1. Second Great Seal of King Henry III, 1259, obverse and reverse

2. Westminster Abbey, portrait of Richard II, $c .1359-9$

3. Westminster Abbey, Cosmati tomb of Henry III, completed c. 1290

4. Life of St Edward, Cambridge University Library 


\section{EDITOR'S PREFACE}

The chapters of this book originated as papers delivered at a series of one-day conferences of the J. K. Hyde Centre for Late Medieval and Renaissance Studies at the University of Manchester. The Centre was established by the late Professor J. K. Hyde to promote interdisciplinary research. Thanks are due to all who attended the conferences and contributed to the wide-ranging discussion on orders and hierarchies. I am especially grateful to Brian Pullan both for his unstinting work on behalf of the J. K. Hyde Centre and for his unfailingly generous assistance in the preparation of this book. For constant forbearance and support, not least in solving the enigmas created by variously processed contributions, my heartfelt thanks go to David Shepherd.

JefFrey Denton 


\section{NOTES ON THE CONTRIBUTORS}

Peter Ainsworth is Professor of French at the University of Liverpool. Author of Jean Froissart and the Fabric of History (1990), he has also published recently on Marie de France. With George Diller, he is preparing a partial edition of Books II and III of Froissart's Chroniques for the Lettres Gothiques series, and a new edition of Book III (Besançon MS 865) is also in preparation.

Paul Binski is Lecturer in the History of Art at the University of Cambridge, and has taught at the Universities of Yale and Manchester. He is the author of The Painted Chamber at Westminster (1986) and Westminster Abbey: Kingship and the Representation of Power 1200-1400 (1995), as well as numerous studies of English royal art patronage. His most recent book is Medieval Death, Ritual and Representation (1996).

Antony Black is Professor in the History of Political Thought in the Department of Politics at the University of Dundee. He has written on conciliarism (Council and Commune, 1979), on guilds and communes (Guilds and Civil Society in European Political Thought from the Twelfth Century to the Present (1984), and Community in Historical Perspective (1990), an edition of a translation of selections from Gierke, Das deutsche Genossenschaftsrecht, vol. 1) and also a general study Political Thought in Europe 1250-1450 (1992). He is now working on a history of political thought under Islam with a view to producing a comparative study of the development of political ideas in the Middle East and in Europe.

Michael Bush left the History Department of Manchester University in 1994 to pursue a career in historical research. As a comparative historian, he has written a two-volume work entitled The European Nobility (1983, 1988), The English Aristocracy (1984), and several articles on 
tenant right and serfdom. As a Tudor historian, he has written The Government Policy of Protector Somerset (1975) and a two-volume study of the Pilgrimage of Grace and its aftermath, The Pilgrimage of Grace: A Study of the Rebel Armies of October 1536 (1996; second volume forthcoming). He has also produced a modern edition of Richard Carlile's Every Woman's Book (1826) entitled Richard Carlile's Philosophy of Sex (1997); and he has edited Social Orders and Social Classes in Europe since 1500 (1992) and Serfdom and Slavery (1996).

Jeffrey Denton is Research Professor in Medieval History at the University of Manchester. He is the author of English Royal Free Chapels 11001300 (1970), Robert Winchelsey and the Crown 1294-1313 (1980), and (with J. P. Dooley) Representatives of the Lower Clergy in Parliament 12951340 (1987), and editor (with R. G. Davies) of The English Parliament in the Middle Ages (1981). He is working on a monograph, and new editions of texts, concerning royal/ecclesiastical relations, $c .1300$, in France and England.

Maurice Keen was educated at Winchester and at Balliol College Oxford, where he read Modern History, graduating in 1957. Since 1961 he has been a Fellow of Balliol and tutor in medieval history there. His many publications include The Outlaws of Medieval Legend (1961), The Laws of War in the Later Middle Ages (1965), A History of Medieval Europe (1967), England in the Later Middle Ages (1973), and Chivalry (1984).

Spencer Pearce is Lecturer in Italian Studies at the University of Manchester, where he currently teaches courses on Dante and fifteenthcentury Italian art. His principal research interest is in the field of Italian Renaissance thought. He has published articles on Dante, modern Italian poetry, and the Renaissance polymath Girolamo Fracastoro.

Brian Pullan has been Professor of Modern History at the University of Manchester since 1973 and is the author of Rich and Poor in Renaissance Venice (1971), The Jews of Europe and the Inquisition of Venice, 1550-1670 (1983) and Poverty and Charity: Europe, Italy, Venice, 1400-1700 (1994), and the editor of Crisis and Change in the Economy of Venice in the Sixteenth and Seventeenth Centuries (1968) and (with D. Chambers and J. Fletcher) Venice: A Documentary History, 1450-1630 (1992). He is currently 
working on a general history of poverty, charity and poor relief in Italy from the fifteenth to the eighteenth century.

David Rheubottom is Lecturer in Social Anthropology at the University of Manchester. He did anthropological fieldwork on the family and economics in a Macedonian peasant village. More recently he has been working on an anthropological analysis of politics and kinship in late medieval Ragusa (Dubrovnik). He is the author of several studies concerning both Macedonia and Ragusa published since 1976.

Stephen Rigby was educated at the Universities of Sheffield and London and is Reader in Medieval History at the University of Manchester. He is the author of a number of books and articles on social theory and medieval history including Marxism and History: A Critical Introduction (1987), Engels and the Formation of Marxism: History, Dialectics and Revolution (1992), Medieval Grimsby: Growth and Decline (1993), English Society in the Later Middle Ages: Class, Status and Gender (1995) and Chaucer in Context: Society, Allegory and Gender (1996). 